\title{
Control of Pests in Saline Paddy of Percut, Northern Sumatera
}

\author{
Ameilia Zuliyanti Siregar ${ }^{1}$, Y Yurnaliza ${ }^{2}$ \\ \{azsyanti@gmail.com¹, yurnaliza@gmail.com ${ }^{2}$ \} \\ ${ }^{1}$ Departmeny of Agrotechnology, Universitas Sumatera Utara, Medan, Indonesia \\ ${ }^{2}$ Department of Biology, Universitas Sumatera Utara, Medan, Indonesia
}

\begin{abstract}
Rice and fish are an important source of protein for the people of North Sumatra that can be produced from tidal rice cultivation. The research was conducted started from March 2017 to September 2017 using group random design method on two plots of rice plantation in Paluh Merbau Sub-district, Percut Sei Tuan, North of Sumatra. Comparison between IR 64 paddy types with nila tilapia (Tilapia mosambicca) on two plots, in the control area and tidal area are predicted to show a comparison of fish composition and diversity of species of insects identified to family/species levels categorized into 4 groups (Predators, Parasites, Pests, Parasitoids). Yellow Sticky Trap (YST) more effective used than Sweep Net (SN) and Core Sampler (CS) in Paddy of Percut. Calculation of richnesse index of Margallef (R1), Index Jaccard, Shannon-Wiener Diversity Index ( $\left.\mathrm{H}^{\prime}\right)$ in tidal rice fields. Dominant pests such as Orseolia oryzae and Leptocorisa oratorius are controlled using environmentally friendly bioinsecticides, such as . T-Test, Kruskal-Wallis test and correlation test showed significant differences between the abundance and the dominance of insects in the control and tidal areas; the effectiveness of insect trap testing and the most effective use of vegetable pesticides. Furthermore, differences in insect biodiversity during the sampling period and phase of paddy were affected by physical, chemical, and biological factors in Percut Sei Tuan, North of Sumatra.
\end{abstract}

Keywords: Potential used, natural pesticide, O. oryzae, L.oratorus, Percut

\section{Introduction}

Efforts to increase agricultural production, especially rice crops are done, among others by the use of superior varieties. The use of improved varieties has consequences for the increase of pesticide applications as pest populations increase, biodiversity decreases. This can threaten sustainable agriculture systems. The facts on the ground suggest that rice plant pests have various types of natural enemies. Among the natural enemies, there are various types of arthropods as parasitoids and predators. The role of increasing natural enemy populations is necessary to achieve sustainable agricultural systems. Biodiversity prior to integrated pest management (IPM), especially in the IPM implementation area is simpler (less) than after IPM, especially biological agents as the main control of the primary pest of rice crops. The main pests of rice plants, among others planthopper and rice stem borer. Prior to IPM implementation, natural enemies were unable to suppress both populations of the pests. Conversely after the implementation of IPM, natural enemies can reduce pest populations. The natural enemies of the apes are Lycosa pseudoannulata Boes. Et Berg., Coccinella sp. 
Paederus sp., Ophionea sp., Cyrtorhinus lividipennis Reuter., Oligosita sp., Anagrus sp., and Gonatocerus sp. Natural enemies of rice stem borer, among others Trichogramma japonicum Ashm., Telenomus rowani Gah, and Tetrastichus schoenobii Ferr. The potential of natural enemies, especially parasitoids and predators is large enough to decrease pest populations, in terms of growth rate and prey ability. To enhance and sustain natural enemies, carried out by means of preservation of biological agents, weed management and crop residue and provision of artificial feed.

It is known that various types of natural enemies are divided into 3 groups, namely parasitoids, predators, and pathogens. There are 79 types of natural enemies of brown planthopper pest (WBC), among which 34 parasitoids, 37 predators, and 8 pathogens (Chiu, 1979). The potential natural enemy for rice stem borer (PBP) is the parasitoid. There are 3 types of PBP parasitoids, namely: Tetrastichus schenobii Ferr., Telenomus rowani Gah., and Trichogramma joponicum Ashm (Jepson, 1954; Soehardjan, 1976). To date, 36 species of insect pathogenic fungi (JPS) have been observed in rice plants (Carruthers \& Hural, 1990). Among these pathogens, Hirsutella citriformis, Metarrhizium anisopliae and Beauveria bassiana have the potential to control the WBC. Parasitoids and predators are able to degrade pest populations, whereas JPS infections can kill and affect pest development, decrease reproductive capacity, and decrease pest resistance against predators, parasitoids and other pathogens (Wardojo, 1986).

The paddy ecosystem is theoretically an unstable ecosystem. The stability of the paddy ecosystem is not only determined by the diversity of community structures, but also by the nature of the components and the interactions between ecosystem components. The results of the study on habitat studies showed that no less than 700 insects including parasitoids and predators were found in the paddy ecosystem under no pest plant conditions, notably the WBC. The results show that rice farming communities are diverse (Untung, 1992). If intercomponent interactions can be managed appropriately, the stability of agricultural ecosystems can be maintained. Thus it is possible that the agricultural ecosystem can create a stable state. To maintain a stable rice farming ecosystem, the concept of IPM can be applied. Insecticides are the last alternative and their use is highly selective. In the rice fields, natural enemies clearly function, resulting in a biological balance (Baehaki, 1991). This biological balance is sometimes accomplished, but it can be otherwise. This is due to other factors that affect, namely agronomic treatment and the use of insecticides. The Orseolia oryzae and Leptocorisa oratorius are quites diversies in saline paddy cultivation in Percut.

\section{Methodology}

The sampling of insect pests and their natural enemies was carried out in ricefield of tidal rice at Percut, North Sumatera in May 2017 until August 2017. The sampling method was done by the relative method by using 3 traps (Stick yellow trap, Sweep net and Core sampler) for observation was determined 5 plots as randomly selected stations with each area. The land is about $15 \times 20 \mathrm{~m} 2$. Sampling is conducted once a week during vegetative phase and generative phase of tidal ricefield to directly observe and collect of insects in the control and fish farming sites. Catching insects performed at 08:00 to 10:00am. Observations made include counting the number of insects caught at a given number of points used ( Preap et al., 2001; Khan et al, 1991; Alonzo et al, 1994). 
This study used Randomized Block Design (RBD) on rice farming and controlled with several types of vegetable pesticides, consisting of 4 treatment levels in which each treatment received $0.03 \mathrm{ml}$ MOL snail mas, while 4 treatment levels and each treatment on repeated 3 times with 5 plant samples. Factors studied in the study include Combination of vegetable pesticide consisting of: $\mathrm{P} 0=$ Control, $\mathrm{P} 1=$ Neem leaf extract $100 \mathrm{ml}, \mathrm{P} 2=$ Pepaya leaf extract $100 \mathrm{ml}, \mathrm{P} 3=100 \mathrm{ml}$ poison yam plant extract. Total samples of plants observed were 60 plants for each land, namely control and paddy fields. Data obtained on each capture were calculated and identified and then analyzed by calculating Richnesse Margalef's index (R1) and Evenness index (E) and Jaccard Index. While the diversity of Shanon-Weaner $(\mathrm{H})$ $(12,13,14,15)$ species was recorded as follows: Diversities index is low if $\mathrm{H}<1$; Diversities index is moderate if $1 \leq \mathrm{H} \leq 3$; and Diversities index is higher if $\mathrm{H}>3$. Soil physical measurements taken are $\mathrm{pH}$ measurement, temperature measurement, light intensity, wind speed, soil DHL, number of fertilization and leaf color measurement.

\section{Results And Discussion}

The calculations of insects, such as the order, family, genus / species, number, insect status collected in Percut, Sumatera Utara can be seen in table 1 below. Insects are categorized into 4 groups (Predators, Parasites, Pests, Parasitoids). In the research location of rice cultivation were recorded 23 species of predators (Lycosa sp, Tetagrantha sp, C. septempunctata, Hydrobius sp, Hydrophilus sp, Leptispa sp, Paederus sp, Componatus sp, Formocarfatus sp, A. femina, A. pygmaea, I senegalensis, P rubriceps, C. servilea,D. trivialis, N. ramburii, N. terminata, N.tullia, O. sabina, P.flavescens, T. aurora, T. tillarga, A. lata); 2 parasites (Anisop sp and Culex sp), 11 pests (Orseolia oryzae, Hydrellia sp, Atherigon sp, L.orotarius sp, Nephotettix sp, N.lugens, Cnaphalocrocis medinalis, Pelopide sp, S.incertulas, S.inonata, Pomacea sp), 2 parasitoids (Aphis sp, Tabanus sp) and 2 species without status, such as Battilaria sp and Stanicophora (Table 1).

Table 1. Composition and distribution of insects in paddy of Percut

\begin{tabular}{|c|c|c|c|c|c|c|}
\hline Orders & Families & Genera/spesies & Status & Local name & $\begin{array}{l}\text { Total } \\
\text { paddy } \\
\text { cultivation }\end{array}$ & $\begin{array}{l}\text { Total } \\
\text { Fish } \\
\text { farming }\end{array}$ \\
\hline Aranea & Lycosidae & Lycosa $s p$ & Predator & Laba-laba & 730 & 245 \\
\hline Aranea & Lycosidae & Tetagrantha sp & Predator & Laba-laba & 434 & 195 \\
\hline Cerithio & Battilaridae & Battilaria sp & - & Kecoak air & 290 & 134 \\
\hline Coleoptera & Coccinellidae & $\begin{array}{l}\text { Coccinella } \\
\text { septempunctata }\end{array}$ & Predator & Kumbang & 174 & 51 \\
\hline Coleoptera & Hydrophilidae & Hydrobius sp & Predator & Kumbang & 23 & 21 \\
\hline Coleoptera & Hyrophillidae & Hydrophillus sp & Predator & Kumbang & 37 & 32 \\
\hline Coleoptera & Chrysomelidae & Leptispa sp & Predator & Leptispa & 71 & 17 \\
\hline Coleoptera & Staphylidae & Paederus sp & Predator & Tomket & 57 & 56 \\
\hline Diptera & Anisopodidae & Anisop sp & Parasit & Agas & 2436 & 7 \\
\hline Diptera & Cecidomylidae & Orseolia oryzae & Pests & Ganjur & 8217 & 7.104 \\
\hline Diptera & Culicidae & Culex sp & Parasit & Nyamuk & 21 & 91 \\
\hline Diptera & Ephydridae & Hydrellia sp & Pests & Lalat bibit & 247 & 241 \\
\hline Diptera & Muscidae & Atherigon $s p$ & Pests & Lalat bibit & 172 & 35 \\
\hline Diptera & Tabanidae & Tabanus sp & Parasit & Lalat & 36 & 18 \\
\hline Hemiptera & Alydidae & L.orotarius sp & Pests & Walang sangit & 2880 & 51 \\
\hline Hemiptera & Chrysomelidae & Nephotettix $s p$ & Pests & Wereng hijau & 87 & 247 \\
\hline Hemiptera & Delphacidae & N.lugens & Pests & WBC & 87 & 84 \\
\hline Hemiptera & Pentatomidae & Scatinophora sp & - & Kepinding & 329 & 42 \\
\hline
\end{tabular}




\begin{tabular}{|c|c|c|c|c|c|c|}
\hline Orders & Families & Genera/spesies & Status & Local name & $\begin{array}{l}\text { Total } \\
\text { paddy } \\
\text { cultivation }\end{array}$ & $\begin{array}{l}\text { Total } \\
\text { Fish } \\
\text { farming }\end{array}$ \\
\hline & & & & tanah & & \\
\hline Hymenoptera & Apidae & Aphis sp & Parasitoid & Lebah & 290 & 40 \\
\hline Hymenoptera & Formicidae & Componotus sp & Predator & Semut & 72 & 25 \\
\hline Hymenoptera & Formicidae & Fomocarfatus $s p$ & Predator & Semut merah & 177 & 78 \\
\hline Lepidoptera & Pyralidae & $\frac{\text { Cnaphalocrocis }}{\text { medinalis }}$ & Pests & Hama Putih & 576 & 358 \\
\hline Lepidoptera & Crambinidae & Pelopida $s p$ & Pests & Ngengat & 144 & 17 \\
\hline Lepidoptera & Crambidadae & S.incertulas & Pests & Ngengat & 61 & 59 \\
\hline Lepidoptera & Crambidae & S.inonata & Pests & Ngengat & 41 & 32 \\
\hline $\begin{array}{l}\text { Mesogastro } \\
\text { poda }\end{array}$ & Ampullaridae & Pomacea sp & Pests & Keongmas & 54 & 54 \\
\hline Odonata & Coenagrionidae & A.femina & Predator & Capung & 85 & 78 \\
\hline Odonata & Coenagronidae & A.pygmaea & Predator & Capung & 26 & 12 \\
\hline Odonata & Coenagrionidae & I.senegalensis & Predator & Capung & 92 & 24 \\
\hline Odonata & Coenagrionidae & P.rubiceps & Predator & Capungbiru & 125 & 15 \\
\hline Odonata & Libellullidae & C.servillia & Predator & Capung & 212 & 9 \\
\hline Odonata & Libellulidae & D.trivialis & Predator & Capung & 87 & 6 \\
\hline Odonata & Libellulidae & N.ramburii & Predator & Capung & 31 & 0 \\
\hline Odonata & Libellulidae & N.terminata & Predator & Capung & 5 & 0 \\
\hline Odonata & Libellulidae & N.tullia & Predator & Capung & 3 & 0 \\
\hline Odonata & Libellullidae & O.sabina & Predator & Capung & 96 & 0 \\
\hline Odonata & Libellullidae & P.flavescen & Predator & Capung & 46 & 0 \\
\hline Odonata & Libellulidae & T.aurora & Predator & Capung & 7 & 0 \\
\hline Odonata & Libellullidae & T.tillarga & Predator & Capung & 72 & 0 \\
\hline Orthoptera & Tetrigidae & $\begin{array}{l}\text { Atractomorpha } \\
\text { lata }\end{array}$ & Predator & Belalang & 29 & 0 \\
\hline
\end{tabular}

The table above described the dominant the percentage of insects caught in the entire experimental field in the generative phase can be seen in Figure 2. There are L. oratorius, O.oryzae. Formocartus sp, Lycosa sp and N.lugens were distributed, while the less of insects recorded from 4 species (Anisop, C.servilea, T.aurora, Gyrllus) described into Figure 1.

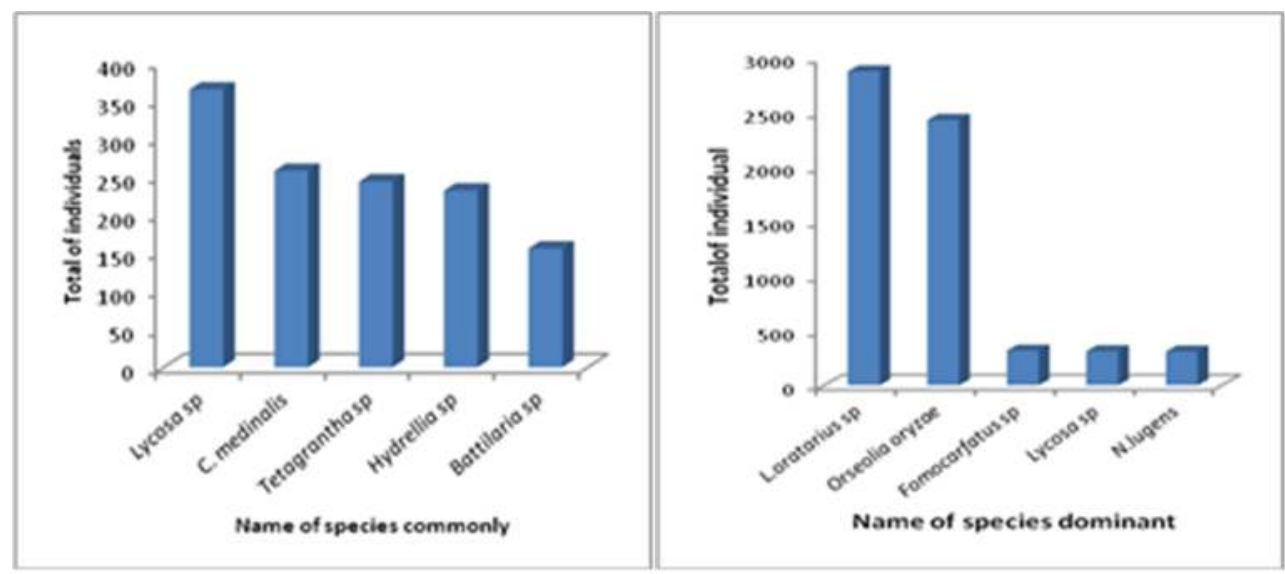

Fig.1. The Dominant Pests in Paddy of Percut

In the generative phase of many caught insect pests are Leptocorisa oratorius (2877 individuals), Orseolia oryzae (2431 individuals), Fomacarfatus sp (318 individuals), Lycosa sp (313 individuals) and Nilaparvata lugens (310 individuals). Meanwhile the less of insects 
collected from Anisop sp (1 individual), but C.servilea, Tholymis aurora and Gryllus sp each 2 individuals (Figure 2). Spesies of $L$. oratorius undergoes a simple metamorphosis whose development begins from egg stadia, nymph and imago. Imago shaped like a ladybug, slim, antenna and legs are relatively long. Body color green brownish yellow and long ranged between $15-30 \mathrm{~mm}$ (Bonhoff et al., 1997). Eggs: Eggs are shaped like dark red discs and are placed on a regular basis in groups. The egg group usually consists of 10-20 grains. The eggs are usually placed on the top surface of the leaf near the mother's leaf bone. Laying eggs generally done at the time of flowering rice. Eggs will hatch $5-8$ days after being laid. The development from egg to imago is 25 days and one generation reaches 46 days (Uphoff, 2004; Alonso et al., 1994; Kandibane et al., 2005; Asahina, 1979). Nymph: The nymph is yellowish, sometimes the nymph is invisible because of its color same with leaf color. Stadium nymph 17 - 27 days consisting of 5 instars (Bonhof et al., 1997). Imago: Imago of L.oratorius that live on rice plants, ventral part the abdomen is brownish yellow and living on the grass of parts $\mathrm{v}$, 1979entral abdomen is whitish green. Spawn on the top leaf surface rice and other grasses in groups in one to two rows (18). Active attack in the morning and afternoon, while in the daytime shelter under a damp and cold tree (Uphoff, 2004). A good development for L.oratorius pests occurs at temperatures between $27^{\circ}-30^{\circ} \mathrm{C}$.

The development of L.oratorius has been known to be the symptoms of attack and damage caused at the time of moderate temperatures, low rainfall and sunlight bright. The L.oratorius can breed in lowland plains and in the plains high (Barlow et al., 1982). Symptoms of attack and damage: the nymph and imago suck the grain of the rice in the milk cooking phase, otherwise it can also suck liquid rice stalk. The blinds are sucked into a hollow and are blackish brown. The L.oratorius suck the rice bleed liquid by piercing the stylet. Nymph is more active than imago, but imago can damage more because of his life longer. The loss of seed fluid causes the paddy seed to shrink if the fluid is in the seed not spent. In the absence of mature grain, it can attack grains of rice that begin to harden, so that when the stylet is stuck out enzyme which can digest carbohydrates (Alonso et al., 1994). Species of L. oratorius is due low-intensity rainfall conditions, inconsistent planting, and around the land many weed plants (Barrion and Litsinger, 1994). Symptoms of L.oratorius attack can be seen. This is assumed because rice varieties are planted resistant against $N$. lugens attack. Then in table 2 showed the potential used of physical (traps) such as Yellow Sticky Trap (YST) more effective used than Sweep Net (SN) and Core Sampler (CS) in Paddy of Percut.

Table 2. The potential used of physical (traps) in Paddy of Percut

\begin{tabular}{lcccccc}
\hline \multicolumn{1}{c}{$\mathrm{T}$} & Df & $\begin{array}{c}\text { Sig. } \\
\text { (2-tailed) }\end{array}$ & $\begin{array}{c}\text { Mean } \\
\text { Difference }\end{array}$ & \multicolumn{3}{c}{$\begin{array}{c}\text { 95\% Confidence Interval } \\
\text { of the Difference }\end{array}$} \\
\hline YST paddy cultivation & 4.582 & 59 & 0.07 & 27.43218 & 8.2410 & 40.5321 \\
\hline SN paddy cultivation & 3.012 & 59 & 0.05 & 14.72500 & 6.5117 & 19.9420 \\
\hline CS paddy cultivation & 1.958 & 59 & .148 & 6.47078 & -.7215 & 5.6016 \\
\hline YST fish farming & 3.748 & 59 & .006 & 25.56716 & 7.1630 & 39.4732 \\
\hline SN fish farming & 2.975 & 59 & .004 & 13.90000 & 5.4217 & 19.7523 \\
\hline CS fish farming & 1.724 & 59 & .169 & 4.58078 & -.5215 & 5.4011 \\
\hline
\end{tabular}

Table 2 shows that many insects are trapped in SN traps, namely Cnaphalocrocis medinalis, Hydrellia sp and C.servilea. These species are commonly found in rice plants, especially in the vegetative phase. In the yellow glue trap (YST), many insects are caught from the O.oryzae, L.oratorius, and Anisop sp. In the core trap device (CS), the most widely caught insects from Lycosa sp, Tetragrantha sp, Scatinophora sp. 
An index of diversity of insect pests in tidal ricefield of Percut, North Sumatra in the two phases can be seen in Table 4. Based on the data it is known the genera is similar between vegetative and generative phases, but that the index of diversity of insect pests in paddy fields at each observation time is always changing. Then the diversity of insects obtained on both experimental estates is between medium to high. In the vegetative phase the highest diversity index was 3.98 and the lowest was 2.87, while in Generative recorded from $\mathrm{H}^{\prime}=3.65$ and lowest with values $\mathrm{H}^{\prime}=2.30$. The use of three tools can control the pest of rice plants in tidal ricefield of Percut, Sumatera Utara. Changes in the diversity index of insect pests in Paddy fields at each time the observation occurs because the population of each organization on every ecosystem is never the same from time to time but there is an increase and decline (Pinheiro e al, 2002).

Table 3. Calculation of Biological indices in Paddy of Percut

\begin{tabular}{lccccccc}
\hline \multicolumn{1}{c}{ Yield } & Order & $\begin{array}{c}\text { Family in } \\
\text { Vegetative and } \\
\text { Generative }\end{array}$ & $\begin{array}{c}\text { General/ } \\
\text { Species }\end{array}$ & R1 & E & Jc & $\begin{array}{c}\text { H' Vegetative } \\
\text { and Generative }\end{array}$ \\
\hline $\begin{array}{l}\text { Paddy } \\
\text { Cultivation }\end{array}$ & 10 & 23 & $\begin{array}{l}40 / 10.337 \\
\text { individuals }\end{array}$ & 1.81 & 0.65 & 0.89 & $3.98 / 3.65$ \\
\hline Fish farming & 10 & 27 & $\begin{array}{l}42 / 8275 \\
\text { individuals }\end{array}$ & 1.93 & 0.72 & 0.95 & $2.87 / 2.30$ \\
\hline
\end{tabular}

The application of chemicals such as fertilizers (urea, nitrate, phosphate, pottasium), herbicides (H-Ally XP) and insecticides (imidacloprid, rhodiamine) in rice cultivation in Percut are applied routinely assumed to affect the enrichment of surface water nutrition (Roja, 2009; Suyamto, 2005), especially after application at the end of the young phase and the beginning of the seedling phase (Borror, Siregar, 2014; Fortunately, 2006). Abundance of aquatic organisms, such as ephemeropterans, odonates, coleopterans and dipterans are influenced by application of rice mina in paddy fields in Purwosari Village, Simalungun. The negative effects of pesticides on aquatic organisms are reported by various researchers (Riasari 2005, Saikia et al, 2015).

\subsection{Biodiversity Of Artropoda At Rice Cultivation}

Seasonal plant ecosystems are less stable which is characterized by low biodiversity. The composition of feed tissue in the ecosystem of simple crops causes the pest population to be in an unbalanced state, making it easy for pest population explosions (Andrewartha \& Birch 1982, Southwbod \& Way 1980). The stability of wetland or seasonal crop ecosystems can be achieved by enhancing and consolidating biodiversity in ecosystems through ecosystem management, inter alia by optimizing cultivation and enhancing the role of natural enemies.

According to Settle et al. (1996), in Indonesia, wetland rice ecosystems are fertile organic matter and are not polluted by pesticides, rich in biodiversity. The wetland rice ecosystem contains 765 species of insects and artificial artropods. The biodiversity consists of detrivora and plankton-eating groups (Culicidae and Chironomidae larvae), herbivores (including insect pests), parasitoids, and predators. By Soenarjo (2000), the composition of fauna biodiversity in wetland ecosystems, based on the findings of Settle et al. (1996) is simplified in tabular form as presented in Table 4 below. 
Table 4. Composition of fauna biodiversity in ricefields of Indonesia

\begin{tabular}{lccccc}
\hline $\begin{array}{l}\text { Detrivore } \\
\text { feeders }\end{array}$ & and & plancton & \multicolumn{4}{c}{ Total of Species } \\
\cline { 3 - 6 } & & & $\begin{array}{c}\text { Herbivor } \\
\mathrm{e}\end{array}$ & $\begin{array}{c}\text { Parasitoi } \\
\mathrm{d}\end{array}$ & $\begin{array}{c}\text { Predato } \\
\mathrm{r}\end{array}$ \\
\hline & 145 & 127 & 187 & Total \\
& $(19 \%)$ & $(17 \%)$ & $(24 \%)$ & $(40 \%)$ & $(100 \%)$ \\
\hline
\end{tabular}

\subsection{Making Biopestisida}

Plants of attractant as a biopesticide used is the core of betel endosperm washed with water and dried for 1 week to reduce water content and then pounded into a powder then filtered with a filter (filter) so as to obtain a powder that is ready to dried. Each of the neem leaves, tobacco leaf, and papaya leaf used is a wide-sized, not too hard, not too young, washed with water, dried for 1 week, then ground into powder. The powder is then filtered with a flour filter. Mengkudu used is the fruit washed, then washed with water and cut into small pieces and dried for 1 week to reduce water content and then pounded into a powder, then each powder dried in the sun so that. In each plot of land placed neem attractiveness (Azadirachta indica) as much as $500 \mathrm{gr}$, then around the rice plants that dominate the attack O.oryzae and L.oratorius sprinkled powder attractiveness of neem leaves, papaya leaves and toxic leaves according to application 130 gr per plot land.

\section{Conclusion}

Different types of arthropods present in wetland rice ecosystems play a role in biological balance to achieve environmentally friendly pest control towards sustainable agriculture. The potential of various types of natural enemies, especially the parasitoids and predators of brown planthopper pests and rice stem borer and preservation methods can be used as a case study of biological agents for the control of other rice plant pests

\section{References}

[1] Adrewartha, H.G. \& L.C. Birch. 1984. The ecological. The University of Chicago. 505 pp.

[2] Alonso Mejia, A. \& Marquez, M. 1994. Dragonfly predation on butterflies in a tropical dry forest. Biotropica 26: 341-344.

[3] Arifin, M, I.B.G. Suryawan, B.H. Priyanto \& A. Alwi. 1997. Diversity of arthropods on various rice cultivation techniques in Pemalang, Central Java. Agricultural Research Puslitbangtan 15 (2): 5-12.

[4] Asahnia, S .1979. An illustrated key to the dragonflies found in the padddy field of Thailand. IABCR-NEWS No.4.

[5] Atmaja, W.R. 1989. Parasitism of Anagrus sp. And Gonatocerus sp. To the eggs of three types of planthopper on rice cultivation and grass. P. 722-729. In Soeprapto et al. (eds.). Proceeding of Bogor Food Crops Research Results. Vol. 3. Bogor, 29 February - 2 March 1992. Indonesian Center for Food Crops Research, Bogor.

[6] Barlow, H. S. 1982. An Introduction to the Moths of South East Asia. The Indonesian Nature Society, Kuala Lumpur. 305 p. 
[7] Barrion, A.T. \& J.A. Litsinger. 1994. Taxonomy of rice insect pests and their arthropods parasites and predators. In Heinrichs EA (Ed.). Biology and management of rice insects. Wiley Eastern Limited. New Age International Limited, New Delhi. Pp. 13-359.

[8] Baehaki S.E. 1991. The role of natural enemies controlling brown planthoppers. Proceedings of a National Day Seminar. Faculty of Agriculture, University of Jenderal Sudirman. p. 19.

[9] Barrion, A.T. \& J.A. Litsinger. 1984. Tabanus spp. (Diptera: Tabanidae) eggs and alternative host of rice stemborer egg parasitic parasitoid Telenomus dignus Gahan (Hymenoptera; Scelionidae). IRRN 9 (6): 19.

[10] Bonhof, M.L.Overholt, W.A. Van huis A \& Polaszek, A. 1997. Natural enemies of cereal stemborers in east Africa: A review. Insect Sci. Applic. 17: 19-35.

[11] Central Bureau of Statistics. 1970-1999. The extent and intensity of the attack on the pest of rice and crops in Indonesia, Jakarta.

[12] Carruthers, R.I. \& K. Hural. 1990. Fungi as naturally occuring entomophatogens, pp. 115-138. InR.R. Baker and P.E. Dunn (eds.). New Directions in Biological Control; Alternative for suppressing agricultural pests and diseases. Alan R. Liss, Inc.

[13] Chiu, S.C. 1979. Biological control of the brown planthopper, Nilaparvata lugens Stal. pp. 335356.In Brown Planthopper Threat to Rice Production in Asia. IRRI, Los Banos, Laguna, Philippines.

[14] Darmawan, D \& Y. Yusdja. 1992. The cost efficiency of pesticides in rice plants with integrated pest control programs, p. 1007-1022. In M. Syam et al. (red). Kineria Food Crops Research, Book 3. Center for Food Crops Research and Development, Bogor.

[15] Fortunately, K. \& M. Sudomo. 1997. Insect management on an ongoing basis. Paper presented at Indonesian Entomology Symposium. Bandung, 24-26 June 1997. 13 p.

[16] Jepson, W.F. 1954. A critical review of the world literature on the Lepidopterous Stalk borers of tropical gramminaceous crops. Commonws. Int. Entomol, London. 127 pp.

[17] Kalshoven, L.G.E. 1981. The pest of crops in Indonesia (Revised and translated by P.A. van der Laan). PT. Ichtiar Baru van Hoeve, Jakarta.

[18] Kandibane, M, Raguraman, S. and Ganapathy, N. 2005. Relative abundance and diversity of Odonata in an irrigated rice field of Madurai, Tamil Nadu. Zoo's Print Journal 20 (11): 20512052.

[19] Kartohardjono, A. 1992. Influence of egg parasitoid Anagrus sp. And Gonatocerus sp. against brown planthopper in two types of host plants. Abstract Collection of Entomology Congress IV, Yogyakarta, 28-30 January 1992. p. 93.

[20] Kartohardjono, A. \& A.R. Marzuki. 1997. Conservation of predators and brown planthopper (Nilaparvata lugens Stal) by spraying host extract and sugar. Abstract Collection of Entomology V Congress and Symposium. Bandung, 23-26 June 1997. p. 41.

[21] Kartohardjono, A. \& W.R. Atmadja. 1997. The preservation of parasitoids (Anagrus sp. and Oligosita sp.) on brown stem leafhoppers (Nilaparvata lugens Stal.) By spraying the host extract and sugar. Proceedings III, National Biology Seminar XV. PBI Branch of Lampung and Unila.

[22] Khan, Z.R. Litsinger, J.A., Barrion, A.T., Villanueva, F.F.D., Fernandez, N.J. \& Taylor, L.D. 1991. World bibliography of rice stem borers 1974-1990. International Rice Research Institutre and International Centre of Insect Physiology and ecology.

[23] Pinheiro, F., Diniz, I. R., Coelho, D. and Bandeira, M. P. S. 2002. Seasonal pattern of insect abundance in the Brazilian cerrado. Austral Ecology 27:132-136.

[24] Preap, V., Zalucki, M. P., Nesbitt, H. J. and Jahn G. C. 2001. Effect of fertilizer, pesticide treatment, and plant variety on realized fecundity and survival rates of Nilaparvata lugens (Stal); Generating Outbreaks in Cambodia. Journal of Asia Pacific Entomology 4(1):75-84.

[25] Profit, I.W. 1995a. Biological aspects of Paederus fuscifes Curt. as a predator of brown planthopper (Nilaparvata lugens Stal.) (Homoptera; Delphacidae). Presented at the National Seminar on Biology towards the Millennium III. Yogyakarta, November 20, 1999. Fak. Biology UGM. 12 pp. 
[26] Profit, I.W. 1995b. Intrinsic growth rate of Cyrtorhinus lividipennis Reuter as predator of brown planthopper (Nilaparvata lugens Stal.) (Homoptera; Delphacidae). Journal of Agricultural Research, University of Islam Sumatera Utara 14 (2): 69-74.

[27] Profit, I.W., D. Kilin \& B. Nurbaeti. 1995. Method of parasitoid propagation of rice stem borer. Report of Research Results. Bogor Research Institute for Food Crops. 15 p.

[28] Marsudiyono. 1989. Effect of residual insecticide on Anagrus sp. parasitic egg of brown planthopper (Nilaparvata lugens Stal.). Thesis Faculty of Biology, National University, Jakarta. $56 \mathrm{p}$.

[29] Rahayu, A. 1986. Carbonyl toxicity, carbofuran, diazinon and quinalfos to N. lugens and C. lividipennis. Seminar on Food Crops Research Results Sukamandi, Puslitbangtan, Bogor Vol. 2: $333-338$

[30] Settle, W.H., H. Ariawan, E. Tri Astuti, W. Cahyono, A.L. Judge, D. Hidayana, A. S. Lestari \& Pajarningsih. 1996. Managing tropical rice pest through concrete of generalist natural enemies and alternative prey. Ecology 77 (7): 1975-1988.

[31] Shepard, B.M., A.T. Barrion \& J.A. Litsinger. 1977. Friend of the rice farmer. Helpful insects, spiders and pathogens. IRRI, Los Banos, Philippines.

[32] Shepard, B.M., H.R. Rapusas \& D.B. Estano. 1989. Using rice straw bundles to conserve beneficial arthropod communities in rice fields. Int. Rice. Res. Newwl. 14 (5): 30-31.

[33] Sivapragasam, A. 1983. Weed host for Cyrtorhinus lividipennis (Reuter), a brown planthopper predator. IRRN 8 (6): 19.

[34] Soehardjan, M. 1976. The dynamics of yellow rice borer population, Tryporyza incertulas (Walker) (Pyralidae; Lepidoptera). ITB dissertation.

[35] Soekarna, D. 1979. Effect of pesticide form EC and WP on some predators of brown planthopper, Nilaparvata lugens Stal. Congress of Entomology I. Jakarta, 9-11 January 1979. 17 p.

[36] Soenarjo, E. 2000. Analysis of brown planthopper explosion and control in endemic areas. Center for Food Crops Research and Development, Bogor. 60 p.

[37] Soenarjo, E. 1986. The existence of a parasite of paddy rice, Orseolia oryzae (Wordmason) in Imperata grass, Orseolia javanica Kieffer. P. 352-356. Minutes of Seminar on Food Crops Research in Sukamandi (2):14-18.

[38] Southwood, T.R.E. \& M.J. Way. 1980. Ecological background to pest management. In R.L. Rabb \& F.E. Guthrie (eds.). Concept of Pest Management. North Caroline State University. Releight, North Caroline.

[39] Supriyadi, S. Mangundihardjo \& E. Mahrub. 1992. An ecological study of wolf spiders, Lycosa pseudoannulata Boes. Et Str. On rice fields. Abstract Collection of Entomology Congress IV. Yogyakarta, January 28-30. p. 91.

[40] Untung, K. 1992. Concept and strategy of integrated pest control. PHT Implementation Symposium Paper. PEI Branch Bandung. Sukamandi, 3-4 September 1992. 17 p.

[41] Uphoff, N. 2004. Development of the System of Rice Intensification in Madagascar in participatory research and development for sustainable agriculture and natural resource management: (http:// sri.ciifad.cornell.edu/).

[42] Wardojo, S. 1986. The use of sterile insects, pathogens, hormones and pheromones in the management of plant pests. Aspects of pesticides in Indonesia. Bogor. p. 252-259. 